Oppression and Responsibility 



\section{Oppression and Responsibility}

a wittgensteinian

approach to

pego'connor

social practices

and

moral theory 
Library of Congress Cataloguing-in-Publication Data

O'Connor, Peg, 1965-

Oppression and responsibility : a Wittgensteinian approach to social practices and moral theory / Peg O'Connor.

p. $\quad \mathrm{cm}$.

Includes bibliographical references and index.

ISBN 0-271-02202-7 (cloth : alk. paper)

1. Social ethics-United States. 2. Marginality, Social—United States.

3. Oppression (Psychology) 4. Discrimination-United States.

5. Sociolinguistics—United States. 6. Wittgenstein, Ludwig, 1889-1951.

I. Title.

HN9o.M6 $\mathrm{O}_{36} 2002$

303.3'72'0973-dc21

2001055954

Copyright $(92002$ The Pennsylvania State University

All rights reserved

Printed in the United States of America

Published by The Pennsylvania State University Press, University Park, PA 16802-1003

It is the policy of The Pennsylvania State University Press to use acid-free paper for the first printing of all clothbound books. Publications on uncoated stock satisfy the minimum requirements of American National Standard for Information Sciences-Permanence of Paper for Printed Library Materials, ANSI Z39.48-1992. 
For Ann and Jack

and for Lisa 
How could human behavior be described?

Surely only by sketching the actions of a variety of humans, as they are all mixed up together. What determines our judgment, our concepts and reactions, is not what one man is doing now, an individual action, but the whole hurly-burly of human actions, the background against which we see any action.

—Ludwig Wittgenstein, Zettel, \$567 